\title{
W sprawie tytułu profesora w projektach założeń Prawa szkolnictwa wyższego (Ustawa 2.0)
}

1. Po uzyskaniu przez Polskę w 1918 r. niepodległości, a także w pierwszych latach po zakończeniu II wojny światowej sprawy szkolnictwa wyższego i rozwoju kadry naukowej były w centrum uwagi władz państwowych i społeczeństwa. Lata późniejsze wprawdzie sytuacji tej nie zmieniły, lecz skutkowały wypracowaniem nowych założeń i środków prowadzących do osiągnięcia stawianych celów. Wyznaczały je akty prawne różnej rangi, ustanowione w okresie II Rzeczypospolitej ${ }^{1}$, Polski Ludowej $^{2}$, Polskiej Rzeczypospolitej Ludowej ${ }^{3}$ i III Rzeczypospolitej ${ }^{4}$. W każdym z tych okresów rozwiązaniami prawnymi objęto także awanse naukowe i zawodowe kadry kształcącej, w tym osób kandydujących do tytułu profesora.

${ }^{1}$ Ustawa z dnia 13 VII 1920 r. o szkołach akademickich (Dz.U. Nr 72, poz. 494 ze zm.); Ustawa z dnia 15 III 1933 r. o szkołach akademickich (tekst jedn. Dz.U 1938 Nr 1, poz. 6 ze zm.).

${ }^{2}$ Dekret z dnia 28 X 1947 r. o organizacji nauki i szkolnictwa wyższego (Dz.U. Nr 68, poz. 415 ze zm.).

${ }^{3}$ Ustawa z dnia 14 XII 1951 r. o szkolnictwie wyższym i o pracownikach nauki (Dz.U. 1952 Nr 6, poz. 38 ze zm.); Ustawa z dnia 5 XI 1958 r. o szkołach wyższych (Dz.U. Nr 68, poz. 336 ze zm.); Ustawa z dnia 31 III 1965 r. o stopniach naukowych i tytułach naukowych (Dz.U. Nr 14, poz. 101 ze zm.).

${ }^{4}$ Ustawa z dnia 4 V 1982 r. o szkolnictwie wyższym (Dz.U. Nr 14, poz. 113 ze zm.); Ustawa z dnia 12 IX 1990 r. o tytule naukowym i stopniach naukowych (Dz.U. Nr 65, poz. 386 ze zm.). 
Awans naukowy nie był wartością trwale ustaloną. W II Rzeczypospolitej i w pierwszych latach Polski Ludowej dyktowały go różne potrzeby, zarówno te związane z zapewnieniem kierowania daną katedra, jak i te dotyczące wypełniania nałożonych na nią zadań, w tym zadań naukowych i dydaktycznych. W II Rzeczypospolitej katedrą mógł kierować wyłącznie profesor z zatwierdzoną nominacją tytułu profesora, zwykle dożywotnio. Nie pozostawało to bez wpływu na awanse profesorskie i wyjaśniało obsadę stanowisk profesorskich także w drodze mianowania. Wprawdzie pierwsze lata Polski Ludowej, w ślad za rozwiązaniami lat trzydziestych II Rzeczypospolitej, przyniosły pewne zmiany w tym zakresie (kierownikiem katedry mógł być również profesor nadzwyczajny), nadal jednak gros ówczesnej kadry profesorskiej stanowili profesorowie mianowani, $\mathrm{w}$ drodze postanowienia, przez Prezydenta Rzeczypospolitej. Nie rozwiązywało to w pełni problemu realizacji zadań nałożonych na szkoły wyższe. Nie bez uzasadnienia ówczesne przepisy prawne przewidywały także prawo przyznawania innych tytułów profesora: honorowego, tytularnego, kontraktowego i zastępcy profesora. Lata późniejszych przemian, choć nie od razu od ich przyznawania odstąiły ( $\mathrm{z}$ wyłączeniem tytułu profesora honorowego zachowanego do $1951 \mathrm{r}$. oraz zastępcy profesora - do $1961 \mathrm{r}^{5}$ ), w efekcie w stopniu znaczącym uporządkowały dystynkcję tytułów profesorskich oraz warunki ich przyznawania. Ustawą z 1951 r. dwóm tytułom profesora (nadzwyczajnego i zwyczajnego) wprost już uznanym za tytuły naukowe na powrót przyznano przymiot tytułów nadanych dożywotnio. W roku 1958 wprawdzie dwa tytuły profesora zachowano, zarazem jednak powrócono do nadawania tytułów profesora tytularnego i kontraktowego. Dopiero rok 1965 przyniósł istotne zmiany w tym zakresie. Ustawą z dnia 31 marca 1965 r. o stopniach naukowych i tytułach naukowych, po pierwsze, odstapiono od przyznawania innych tytułów niż tytuł profesora nadzwyczajnego i profesora zwyczajnego, po drugie, nadawanie tytułów (także stopni) naukowych wyłączono spod prawa szkół wyższych. Odtąd ich nadawanie poddano odrębnej regulacji. I tego stanu rzeczy nie zmieniły kolejne ustawy. To, co bez wątpienia było rozwiązaniem nowym, przyniósł rok 1990. Ustawodawca zastąił dwa tytuły naukowe profesora jednym tytułem, a zarazem zachował prawo osób posiadających tytuły profesora zwyczajnego lub profesora nadzwyczajnego do ich używania w dotychczasowym brzmieniu

\footnotetext{
${ }^{5}$ Zob. art. 147 ust. 1 ustawy z dnia 5 XI 1958 r. o szkołach wyższych.
} 
(art. 41 ust. 3 ustawy o tytule naukowym i stopniach naukowych). Przy nadawaniu jednego tytułu profesora pozostała obowiązująca do dziś ustawa z 2003 r.

2. Ustawa z dnia 14 marca 2003 r. o stopniach naukowych i tytule naukowym oraz o stopniach i tytule $\mathrm{w}$ zakresie sztuki ${ }^{6}$ była wiele razy nowelizowana. Szczególne spiętrzenie jej zmian przypadło na lata zapoczątkowane ustawą zmieniającą z roku $2011^{7}$. W tym okresie nowelami ustawę z 2011 r. zmieniono w latach: $2014^{8}, 2015^{9}, 2016^{10}$ oraz $2017^{11}$. Zmiany nimi wprowadzone $\mathrm{w}$ istocie albo dookreślały przepisy nowelizujące wprowadzone w 2011 r. (z wyłączeniem ustawy zmieniającej w 2017 r.), albo odeszły od przyjętego nią kierunku zmian i ich zakresu. Nie może więc dziwić propozycja ministra nauki i szkolnictwa wyższego zapowiadająca z końcem 2016 r. konieczność wprowadzenia nowej ustawy i dla opracowania projektów założeń do niej ogłoszenia konkursu. Z piętnastu złożonych ofert do dalszych prac przyjęto projekty założeń Prawa szkolnictwa wyższego (Ustawa 2.0) trzech zespołów ${ }^{12}$. Projektami objęto także sprawy nadawania tytułu naukowego profesora. Dla każdego z zespołów status quo proponowanych zmian w tym zakresie stanowiła

${ }^{6}$ Dz.U. Nr 65, poz. 595 ze zm.

${ }^{7}$ Artykuł 2 Ustawy z dnia 18 III 2011 r. o zmianie ustawy - Prawo o szkolnictwie wyższym, ustawy o stopniach naukowych i tytule naukowym oraz o stopniach i tytule w zakresie sztuki oraz o zmianie niektórych innych ustaw (Dz.U. Nr 84, poz. 455).

${ }^{8}$ Artykuł 8 Ustawy z dnia 11 VII 2014 r. o zmianie ustawy - Prawo szkolnictwa wyższego oraz niektórych innych ustaw (Dz.U. poz. 1198).

${ }^{9}$ Artykuł 3 Ustawy z dnia 25 IX 2015 r. o zmianie niektórych ustaw w związku ze wspieraniem innowacyjności (Dz.U. poz. 1767).

${ }^{10}$ Artykuł 3 Ustawy z dnia 23 VI 2016 r. o zmianie ustawy - Prawo o szkolnictwie wyższym oraz niektórych innych ustaw (Dz.U. poz. 311).

${ }^{11}$ Ustawa z dnia 21 IV 2017 r. o zmianie ustawy o stopniach naukowych i tytule naukowym oraz o stopniach i tytule naukowym w zakresie sztuki oraz niektórych innych ustaw (Dz.U. poz. 859)

12 Propozycja założeń do ustawy regulujacej system szkolnictwa wyższego, H. Izdebski (kierownik projektu), A. Świergiel, P. Chmielnicki, P. Ruszkowski, W. Misiąg, A. Kiebała, J. Zieliński, Uniwersytet SWPS, Warszawa 2017, dalej „Projekt pierwszy” lub „zespół pierwszy"; Projekt założeń do ustawy Prawo o szkolnictwie wyższym, M. Kwiek z Zespołem: D. Antonowicz, J. Brdulak, M. Hulicka, T. Jędrzejewski, R. Kowalski, E. Kulczycki, K. Szadkowski, A. Szot, J. Wolszczak-Derlacz, Uniwersytet im. Adama Mickiewicza w Poznaniu, Poznań 2016, dalej „Projekt drugi” lub „zespół drugi”; PLUS RATIO QUAM VIS CONSUETUDINIS. Reforma nauki i akademii w Ustawie 2.0. Projekt założeń do ustawy Prawo o szkolnictwie wyższym, pod red. A. Radwana, Oficyna Allerhanda, Kraków 2017, dalej „Projekt trzeci” lub „zespół trzeci”. 
ustawa z 2003 r., w brzmieniu nadanym jej tekstem jednolitym z 2016 r. $^{13}$ Proponowane projektami założeń zmiany mają różny charakter i zasięg od modyfikacji (w stopniu różnym) rozwiązań obowiązującej ustawy do propozycji ustawą tą nieobjętych. To różne podejście w projektach założeń do oceny instytucji tytułu profesora wynika z przyjęcia nimi dwóch modeli rozwiązań: pierwszego - zmierzającego do zachowania tytułu profesora przy nadaniu mu nowej treści oraz drugiego - będącego propozycją odstąpienia od nadawania tego tytułu. Za pozostawieniem tytułu profesora postulują autorzy dwóch pierwszych zespołów, zaś przeciwni temu rozwiązaniu w istocie są autorzy zespołu trzeciego. W każdej z tych propozycji pojawiają się zatem rozwiązania nowe.

Jakkolwiek by je oceniać, stanowiska dwóch pierwszych zespołów można sprowadzić do uwag dotyczących: (1) jednostek organizacyjnych uprawnionych do prowadzenia postępowania o nadanie tytułu profesora, (2) kandydatów do tytułu profesora i stawianych im wymagań, (3) warunków postępowania w przedmiocie nadania tytułu profesora oraz (4) warunków i trybu przedstawienia kandydata do tytułu. Z kolei propozycję zespołu trzeciego - do wskazania warunków obsady stanowiska profesora $\mathrm{w}$ drodze konkursu dla uznania awansu naukowego kadry profesorskiej, przy jednoczesnym odstąieniu od nadawania tytułu profesora w rozumieniu dotychczasowych przepisów.

Ta dwutorowość propozycji nowych rozwiązań odnoszonych do tytułu profesora, a w szczególności ich wdrożenia, aczkolwiek warta uwagi, jest trudna do pogodzenia. W istocie projektodawcę stawia przed wyborem między tradycyjnym, aczkolwiek zmienionym proponowanymi rozwiązaniami, modelem postępowania w przedmiocie nadania tytułu profesora a modelem nowym, proponującym ocenę rozwoju naukowego kandydata i jego awansowanie na kolejno wyższe (jedno $\mathrm{z}$ trzech) stanowisko profesora.

3. Autorzy dwóch pierwszych zespołów nie wyrażają jednoznacznie negatywnej oceny rozwiązań w zakresie ustawowo wskazanych podmiotów uprawnionych do nadawania tytułu profesora (szkoły wyższe, Polska Akademia Nauk, instytuty badawcze ${ }^{14}$, międzynarodowe instytu-

${ }^{13}$ Obwieszczenie Marszałka Sejmu Rzeczypospolitej Polskiej z dnia 3 VI 2016 r. w sprawie ogłoszenia jednolitego tekstu ustawy o stopniach naukowych i tytule naukowym oraz o stopniach i tytule w zakresie sztuki (Dz.U. poz. 882 ze zm.).

${ }^{14}$ Ustawa z dnia 30 IV 2010 r. o Polskiej Akademii Nauk (tekst jedn. Dz.U. 2016, poz. 572); Ustawa z dnia 30 IV 2010 r. o instytutach badawczych (tekst jedn. Dz.U. 2017, poz. 1158). 
ty naukowe działające na terytorium Rzeczypospolitej Polskiej - posiadające prawo do habilitowania). Podnoszą natomiast potrzebę zmiany rozwiązań normujących: (1) ocenę poziomu działalności naukowej podmiotu uprawnionego do habilitowania jako wyznacznika kategorii naukowej jednostki oraz (2) warunki tzw. minimalnej liczby zatrudnionych przyjętej dla każdej z nich. W kwestii pierwszej propozycje dwóch pierwszych zespołów mają walor w dwójnasób istotny, także dla postępowania w przedmiocie nadania tytułu profesora. Po pierwsze, ocenę kategorii naukowej, mierzonej w procesie parametryzacji, sprowadzają do faktycznie osiągniętych i wartościowych efektów działalności naukowej jednostki organizacyjnej, dotąd oderwanej od jakości prowadzonych w niej badań. Po drugie, proponują ocenę przez Centralną Komisję do Spraw Stopni i Tytułów (CK) poziomu naukowego jednostki na podstawie wyników parametrycznej oceny jej działalności naukowej, zweryfikowanej przez Komitet Ewaluacji Jednostek Naukowych (KEJN), a także przyznanej kategorii (A+ lub A1 - według nowych założeń) ${ }^{15}$. Są to bez wątpienia propozycje słuszne, jakkolwiek by nadawanych kategorii nie nazywać. W istniejącym stanie prawnym CK nie ma bowiem obowiązku odwoływania się do kategorii przyznanej przez KEJN w wyniku parametryzacji dla przyznania uprawnienia do nadawania stopnia doktora habilitowanego lub dla jego odmowy. Propozycja ta ma także inny walor. Może bez przeszkód prowadzić do uznania nadanej danemu podmiotowi kategorii A+ lub A (według dotychczasowych rozwiązań) jako instrumentu oceny działalności naukowej bez względu na to, czy ustawodawca optować będzie za zachowaniem habilitacji czy za odstąpieniem od niej. W kwestii drugiej natomiast dwa pierwsze zespoły opowiadają się za znacznym podwyższeniem tzw. minimalnej liczby zatrudnionych $\mathrm{w}$ jednostkach organizacyjnych posiadających prawo do habilitowania lub wnioskujących o jego nabycie ${ }^{16}$, i to bez względu

\footnotetext{
${ }^{15}$ Projekt drugi, s. 93.

${ }^{16}$ Ustawa z 2003 r. w brzmieniu nadanym w 2016 r. dla warunku minimalnej liczby osób wymaga zatrudnienia w pełnym wymiarze czasu pracy (osoby zatrudnione nie krócej niż rok w danej jednostce organizacyjnej) co najmniej dwunastu osób posiadających tytuł profesora lub stopień naukowy doktora habilitowanego lub osób, które nabyły uprawnienia równoważne $\mathrm{z}$ uprawnieniami doktora habilitowanego na podstawie art. 21a, dla których ta jednostka jest podstawowym miejscem pracy, w tym co najmniej trzech osób posiadających tytuł profesora. Przy tym uprawnienie do nadawania stopnia doktora habilitowanego może obejmować tylko te dyscypliny naukowe (lub artystyczne), które w danej jednostce organizacyjnej są reprezentowane przez co najmniej pięć osób zatrudnionych w pełnym wymiarze czasu pracy, posiadających tytuł profesora
} 
na proponowane zakończenie postępowania habilitacyjnego ${ }^{17}$. Przy tym jedynie zespół drugi propozycję tę konkretyzuje podwyższeniem progu minimum do co najmniej osiemnastu osób z tytułem naukowym profesora lub stopniem doktora habilitowanego, $\mathrm{w}$ tym dziewięciu profesorów oraz ośmiu doktorów habilitowanych $-\mathrm{z}$ danej dziedziny nauki odpowiadającej prowadzonej habilitacji ${ }^{18}$. Oba zespoły zgodne są także w słusznie przyjętej negatywnej ocenie obejmowania liczbą tzw. minimum kadrowego osób posiadających uprawnienia równoważne $\mathrm{z}$ uprawnieniami doktora habilitowanego na podstawie art. $21 \mathrm{a}^{19}$.

Dwa pierwsze zespoły jako niepodlegające dyskusji proponują zachowanie prawa do nadawania tytułu profesora $\mathbf{w}$ dziedzinie nauki (dziedzinie sztuki) ${ }^{20}$. Przy jednoczesnym przez nie założeniu potrzeby redefinicji dziedzin nauki i dyscyplin naukowych dla nabycia lub zachowania uprawnienia do nadawania stopni naukowych, otwarte pozostaje zatem pytanie, które z jednostek organizacyjnych ostatecznie będą mogły uzyskać prawo do habilitowania. Nie pozostaje to bez wpływu na dobór jednostek uprawnionych do nadawania tytułu profesora, nawet przy zachowaniu jego nadawania wyłącznie w dziedzinach nauki. O tym, które z nich będą mogły prowadzić postępowanie w przedmiocie nadania tego tytułu, decydować będą nie tylko względy dotyczące

lub stopień doktora habilitowanego lub osób, które nabyły uprawnienie równoważne z uprawnieniem doktora habilitowanego (art. 6 ust. 2-4).

${ }^{17}$ Projekt pierwszy, s. 54; Projekt drugi, s. 40.

${ }^{18}$ Projekt drugi, s. 162.

${ }^{19}$ W myśl nadal obowiązującego art. 21a, dodanego ustawą zmieniającą w $2011 \mathrm{r}$. ustawę o stopniach naukowych i tytule naukowym oraz o stopniach i tytule w zakresie sztuki z 2003 r., chodzi tu o osoby, które uzyskały stopień doktora w Rzeczypospolitej Polskiej lub za granicą i podczas pracy w innym państwie przez co najmniej pięć lat kierowały samodzielnie zespołami badawczymi oraz posiadają znaczny dorobek i osiągnięcia naukowe, zatrudnione na stanowisku profesora nadzwyczajnego lub profesora wizytującego i nabyły uprawnienie równoważne z posiadaniem stopnia doktora habilitowanego, od 2015 r. na podstawie decyzji: rektora - w przypadku zatrudnienia w szkole wyższej, dyrektora instytutu naukowego PAN - osoby zatrudnionej w PAN, dyrektora instytutu badawczego - osoby zatrudnionej $\mathrm{w}$ danym instytucie badawczym (art. 3 ustawy z 2015 r. o zmianie niektórych ustaw w związku z wprowadzeniem innowacyjności). Decyzja w tym przedmiocie wydana wchodzi w życie po upływie czterech miesięcy od dnia jej otrzymania przez CK, jeżeli ta w tym okresie nie wyrazi, w drodze decyzji, sprzeciwu lub nie uchyli tej decyzji. Na decyzję CK służy rektorowi bądź dyrektorowi instytutu naukowego prawo złożenia skargi do wojewódzkiego sądu administracyjnego (art. 3 ustawy z dnia 25 IX 2015 r. o zmianie niektórych ustaw w związku ze wspieraniem innowacyjności).

${ }^{20}$ Projekt pierwszy, s. 55; Projekt drugi, s. 49. 
wyboru między uprawnieniem do nadawania stopnia doktora habilitowanego $\mathrm{w}$ dziedzinach nauki czy $\mathrm{w}$ dyscyplinach naukowych, ale także w powiązaniu z kategorią naukową A+ lub A (w przypadku szkół wyższych - zgodnie z propozycją rozwiązań - badawczych i badawczo-dydaktycznych). $Z$ tego powodu, a także ze względu na założenie, że CK wyposażona w prawo nadawania uprawnień do habilitowania nie ma prawnego obowiązku uwzględniania kategorii naukowej jednostki organizacyjnej, zespół pierwszy proponuje wariantowo albo „połączenie Centralnej Komisji ds. Stopni i Tytułów oraz Komitetu Ewaluacji Jednostek Naukowych (przy usytuowaniu organu powstałego w wyniku połączenia, pochodzącego z wyborów środowiska, przy ministrze właściwym do spraw nauki), albo stworzenie mechanizmu współdziałania KEJN i CK, polegającego na obowiązku zasięgnięcia przez właściwy $\mathrm{z}$ tych organów opinii drugiego z organów w sprawach oceny jednostek naukowych" ${ }^{\prime 21}$. W przeciwnym razie organem właściwym powinna pozostać CK - działająca po zasięgnięciu opinii Rady Głównej Nauki i Szkolnictwa Wyższego ${ }^{22}$. Podobne stanowisko zajmują także autorzy zespołu drugiego, dostrzegający potrzebę wzmocnienia roli CK połączonej ze zmianą logiki przyznawania uprawnień do nadawania stopni naukowych ${ }^{23}$.

Do innej oceny prowadzą uwagi dotyczące wymagań stawianych przed kandydatami do tytułu profesora. Autorzy dwóch pierwszych zespołów nie odnoszą ich do każdego $\mathrm{z}$ warunków określonych ustawą z 2003 r. w brzmieniu nadanym w 2016 r., sprowadzonych do dwojakiego rodzaju osiągnięć: (1) naukowych oraz (2) w opiece naukowej. $\mathrm{W}$ odniesieniu do pierwszej grupy wymagań ${ }^{24} \mathrm{~W}$ ocenie zespołu pierwszego podstawę do nadania kandydatowi tytułu profesora powinno

\footnotetext{
${ }^{21}$ Projekt pierwszy, s. 55.

22 Ibidem.

${ }^{23}$ Projekt drugi, s. 163.

${ }^{24}$ Ustawa z 2003 r. w brzmieniu nadanym jej tekstem jednolitym w 2016 r. oraz Rozporządzenie Ministra Nauki i Szkolnictwa Wyższego z dnia 26 IX 2016 r. w sprawie szczegółowego trybu i warunków przeprowadzania czynności w przewodzie doktorskim, w postępowaniu habilitacyjnym oraz w postępowaniu o nadanie tytułu profesora (Dz.U. poz. 1586), w zakresie osiągnięć naukowych od kandydata do tytułu profesora wymagają ponadto doświadczenia w kierowaniu zespołami badawczymi realizującymi projekty finansowane $\mathrm{w}$ drodze konkursów krajowych lub zagranicznych bądź odbycia staży naukowych, w tym zagranicznych, lub prowadzenia prac naukowych, w tym zagranicznych, objętych autoreferatem. Od kandydata wymagają także przedłożenia informacji o działalności popularyzującej naukę lub sztukę.
} 
stanowić uznanie jego „szczególnych osiągnięć w sferze nauki [...]”25, podczas gdy do nabycia stopni naukowych nadal wystarczy "uznanie odpowiedniego poziomu przeprowadzonych badań (prac twórczych)"26. Kryterium szczególnych osiągnięć naukowych w odróżnieniu od rozwiązań dotychczasowych (osiągnięć znacznie przekraczających wymagania stawiane w postępowaniu habilitacyjnym) jest bez wątpienia pojęciem szerszym, sugeruje gradację oceny stopnia osiągnięć w tym zakresie. I w tym znaczeniu jest propozycją kontrowersyjna, niejasno wyrażoną. $Z$ kolei zespół drugi dostrzega potrzebę podniesienia poziomu prowadzonych badań naukowych, sprowadzając dotychczasowe wymagania do "nisko postawionej poprzeczki" 27 , a ponadto warunek ten wzmacnia koniecznością ich umiędzynarodowienia oraz propozycją wdrożenia „Programu Profesur Państwowych" (PPP), pozwalającego na wyłonienie rokrocznie co najmniej stu profesorów „ulokowanych w najwyżej parametryzowanych jednostkach uczelni: państwowych, krajowych lub o analogicznej nazwie", wyłanianych w drodze konkursu ${ }^{28}$.

W odniesieniu do warunku drugiego z kolei, w 2016 r. określonego ustawą i rozporządzeniem ${ }^{29}$, stanowisko zespołów nie jest dość jednoznaczne. Zespół pierwszy wprawdzie wymaga szczególnych osiągnięć także w kształceniu kadry akademickiej, nie przybliża jednak znaczenia tego pojęcia. W ocenie zespołu drugiego natomiast osiągnięcia kandydata do tytułu profesora w tej sferze działania powinny być zminimalizowane do granic podyktowanych potrzebą koncentrowania się na działalności naukowej i jakości osiągnięć naukowych oraz pozyskiwania funduszy na badania. Zespół ten zatem w zakresie promowania doktorantów pośrednio upatruje zasadność udziału kandydata do ty-

${ }^{25}$ Projekt pierwszy, s. 100.

${ }^{26}$ Projekt pierwszy, s. 99; podobnie Projekt drugi, s. 50.

${ }^{27}$ Projekt drugi, s. 159.

${ }^{28}$ Zespół drugi inicjuje wdrożenie centralnego „Programu Profesur Państwowych” jako instytucji centralnie finansowanej przez ministerstwo szkolnictwa wyższego i nauki i nadzorowanej przez międzynarodowy panel ekspertów, mającego na celu: wspieranie najwybitniejszych naukowców z tytułem profesorskim w ich badaniach z jednoczesnym zapewnieniem im pięcioletniej stabilizacji finansowej (Projekt drugi, s. 157).

${ }^{29}$ Ustawa oraz rozporządzenie z dnia 26 IX 2016 r. dla wykazania przez kandydata osiągnięć w kształceniu kadry naukowej wymagają od niego: uczestniczenia co najmniej raz $\mathrm{w}$ charakterze promotora $\mathrm{w}$ przewodzie doktorskim zakończonym nadaniem stopnia, raz $\mathrm{w}$ charakterze promotora pomocniczego w przewodzie doktorskim zakończonym nadaniem stopnia lub $\mathrm{w}$ charakterze promotora $\mathrm{w}$ otwartym przewodzie doktorskim oraz dwa razy w charakterze recenzenta w przewodzie doktorskim lub w przewodzie habilitacyjnym lub postępowaniu habilitacyjnym. 
tułu profesora w procesie opieki naukowej i kształceniu młodej kadry. W konsekwencji proponuje odrzucenie $z$ dotychczasowych elementów oceny (1) „obowiązku recenzowania w polskich procedurach awansowych, ponieważ możliwość uczestniczenia w charakterze recenzenta $\mathrm{w}$ przewodzie doktorskim lub w przewodzie habilitacyjnym lub w postępowaniu habilitacyjnym w dużej mierze nie jest zależna od osoby ubiegającej się o tytuł profesora" (co warte jest rozważenia), jak i (2) obowiązku promocji doktorantów ${ }^{30}$. Tym samym zespół ten, choć wątku tego nie podnosi, zarazem odrzuca zasadność utrzymania obowiązku nauczyciela akademickiego lub pracownika naukowego w zakresie m.in. pełnienia funkcji promotora (promotora pomocniczego) oraz pełnienia funkcji recenzenta w postępowaniach o nadanie stopnia naukowego ${ }^{31}$.

Co do trybu i warunków przebiegu postępowania w przedmiocie nadania tytułu profesora autorzy projektów założeń zajmują stanowisko ostrożne, proponują zmiany niewielkie bądź nie proponują żadnych. W sposób dorozumiany można zatem przyjać, że potrzebą zmian obejmują jedynie te elementy przez nich podniesione, które w określonym zakresie dotyczą warunków wszczęcia postępowania, wyznaczenia kandydatów na recenzentów oraz poparcia wniosku o nadanie tytułu profesora.

W kwestii pierwszej ustawa z 2003 r., z uwzględnieniem jej kolejnych zmian, przewiduje możliwość wszczęcia postępowania o nadanie tytułu profesora na wniosek kandydata mającego: (1) stopień naukowy doktora habilitowanego lub (2) uprawnienia równoważne z uprawnieniami doktora habilitowanego na podstawie art. 21a ustawy (od 2011 r.). I w tym zakresie przepis ten nie budzi większych wątpliwości ani zastrzeżeń i jest spójny z prawem wyznaczoną procedurą awansów naukowych. Wszczęcie postępowania i jego przeprowadzenie leży nadal w gestii rady (wydziału, naukowej) posiadającej uprawnienie do nadawania stopnia doktora habilitowanego. To, co jest tu istotne, zawiera się natomiast w pytaniu, czy kandydatowi służy prawo wyboru jednostki organizacyjnej do przeprowadzenia postępowania w przedmiocie nadania tytułu profesora ( $w$ istocie jednostki mającej prawo do

${ }^{30}$ Projekt drugi, s. 161.

${ }^{31}$ Zob. art. 30 ustawy z 2003 r. w brzmieniu nadanym ustawą zmieniającą z 2011 r. nadal obowiązującym. Zgodnie z nim „[p]rzyjęcie funkcji promotora, promotora pomocniczego, członka komisji egzaminacyjnej w przewodzie doktorskim, recenzenta $\mathrm{w}$ przewodzie doktorskim lub postępowaniu habilitacyjnym oraz postępowaniu o nadanie tytułu profesora, a także sporządzenie opinii na wniosek Centralnej Komisji jest obowiązkiem nauczyciela akademickiego lub pracownika naukowego". 
habilitowania). Udzielenie odpowiedzi twierdzącej, już niebudzącej wątpliwości, przynosi rok 2015. Do tego momentu żaden ze zmienianych przepisów ustawy z $2003 \mathrm{r}$. nie formułował bowiem expressis verbis takiego prawa. Lukę tę wypełniło dopiero rozporządzenie ministra nauki i szkolnictwa wyższego z tegoż roku ${ }^{32}$.

Wskazanie, kto może wnioskować o nadanie tytułu profesora, nie rozwiązuje jednak problemu właściwości jednostek organizacyjnych uprawnionych do wszczęcia i prowadzenia postępowania o nadanie tytułu profesora. Propozycje zespołów odnośnie do habilitacji zmierzają bowiem w różnych kierunkach. Zespół pierwszy opowiada się za habilitacją zakończoną, na wzór rozwiązań II Rzeczypospolitej, veniam legendi niebędącą stopniem naukowym, zespół drugi za nieobowiązkowym uzyskaniem stopnia doktora habilitowanego, a zespół trzeci za odstąpieniem od habilitacji - z jednoczesnym zastrzeżeniem: „chyba że z jakichkolwiek powodów w przyszłości stopień doktora habilitowanego miałby zostać zachowany" ${ }^{\prime \prime 3}$. Zespoły autorskie projektów założeń proponują zatem odstąpienie od dotychczasowego unormowania, przez zaprojektowanie nowych, różnych jego wariantów, w efekcie będących propozycją projektów rozwiązań prowadzących w niedługim czasie do wdrożenia nowego ładu w zakresie awansów naukowych, opartego na jednym stopniu naukowym (doktora) i jednym tytule (profesora).

Czy propozycjom tym wychodzi naprzeciw nadal obowiązujące rozwiązanie ustawy z 2003 r. przyjęte w jej pierwotnym brzmieniu, a dające CK działającej na wniosek rady właściwej jednostki organizacyjnej, w szczególnych przypadkach, prawo dopuszczenia do wszczęcia postępowania o nadanie tytułu profesora osobie mającej stopień doktora i posiadającej wybitne osiągnięcia naukowe (lub artystyczne), nie można udzielić odpowiedzi twierdzącej. Jest to bowiem dopuszczalny prawem wyjątek od reguły, zgodnie z którym tytuł profesora może być nadany osobie mającej stopień naukowy doktora habilitowanego.

Chodzi więc o zreformowanie awansów naukowych (w niedługim lub dłuższym okresie) prowadzących do tytułu profesora bez zachowania obowiązkowej habilitacji. Oczywiście, odstąpienie od habilitacji czynić będzie powyższe rozwiązanie (dające podstawę do nadania

32 Zob. § 19 Rozporządzenia Ministra Nauki i Szkolnictwa Wyższego z dnia 30 X 2016 r. w sprawie szczegółowego trybu i warunków przeprowadzania czynności w przewodzie doktorskim, w postępowaniu habilitacyjnym oraz w postępowaniu o nadanie tytułu profesora (Dz.U. poz. 1842).

${ }^{33}$ Projekt trzeci, s. 126. 
tytułu profesora osobie ze stopniem doktora) zbędnym, ale w konsekwencji będzie musiało wieść także do nadania prawa do prowadzenia postępowania w przedmiocie nadawania tytułu profesora jednostkom organizacyjnym posiadającym uprawnienie do nadawania stopnia doktora. Nie wspominając już o potrzebie rewizji postanowień w zakresie ewaluacji jednostek organizacyjnych, prowadzącej do zmiany filozofii w ustalaniu parametrów decydujących o przyznanej im kategorii naukowej. Czy na tak daleko idące zmiany gotowy jest projektodawca? $\mathrm{Na}$ podstawie pierwszego projektu ustawy Prawo o szkolnictwie wyższym i nauce ${ }^{34}$ zachowującego habilitacje nie da się odpowiedzieć twierdząco.

Kwestia druga, dotycząca wyznaczenia przez radę właściwej jednostki organizacyjnej liczby recenzentów w postępowaniu o nadanie tytułu profesora i sposobu ich wyboru przez CK, nie stanowi przedmiotu badań zespołów. Jedynie w odniesieniu do tego, kto funkcję tę powinien pełnić, zespół drugi dostrzega konieczność umiędzynarodowienia ${ }^{35}$ oceny kandydatów do tytułu profesora poprzez obowiązkowe włączenie w proces recenzowania również osób „z prestiżowych ośrodków o międzynarodowej renomie" (co budzi zastrzeżenia wobec dostrzegania renomy ponadpaństwowej wyłącznie w kategoriach sporządzanych rankingów ośrodków naukowych, a nie kadry profesorskiej), przy jednoczesnym „zaostrzeniu kryteriów oceny w postępowaniach na tytuł profesora" (bez wskazania tych kryteriów) ${ }^{36}$.

W kwestii trzeciej, dotyczącej poparcia przez radę właściwej jednostki organizacyjnej wniosku o nadanie tytułu profesora, autorzy dwóch pierwszych projektów założeń nie wypowiadają się. Nie czynią tego także w odniesieniu do sytuacji odmowy przez radę poparcia dotyczącego tej materii wniosku. Wobec ustawowego uregulowania środków ochrony prawnej w tym zakresie milczące stanowisko zespołów (z wyłączeniem zespołu pierwszego) nie budzi zastrzeżeń. Z kolei w kwestii czwartej, tj. przedstawienia kandydatów do tytułu profesora, zdania autorów założeń są podzielone. Zespół pierwszy opowiada się za przyznaniem CK (chyba że projektodawca przyjmie tu inne zaproponowane przez ten zespół rozwiązanie) uprawnień organu wyższego stopnia $\mathrm{w}$ postępowaniach $\mathrm{w}$ przedmiocie tytułu naukowego ${ }^{37} \mathrm{i}$ dalszym jego nadawaniem przez Prezydenta RP. Jednocześnie, postulując

\footnotetext{
${ }^{34}$ Projekt z dnia 16 IX 2017 r.

${ }^{35}$ Projekt drugi, s. 50.

${ }^{36}$ Projekt drugi, s. 161.

37 Projekt pierwszy, s. 55.
} 
podniesienie rangi tytułu profesora, który powinien stać się „szczególnym wyróżnikiem uznania osiągnięć akademickich, a nie, jak to się stało w praktyce, kolejnym szczeblem awansowym" ${ }^{\prime 38}$, proponuje odstapienie od dotychczasowej praktyki traktowania tytułu profesora jako trzeciego, kolejnego i zwykłego etapu awansowego. W efekcie, w ocenie autorów tego zespołu, "osoba wnioskująca o nadanie jej tytułu nie może mieć publicznoprawnego roszczenia o pozytywne zakończenie procedury w razie spełnienia ustawowych wymagańn ${ }^{\prime 39}$. Jest oczywiste, że uchwała rady popierająca wniosek o nadanie tytułu profesora oraz uchwała CK o przedstawieniu kandydata do tytułu profesora do takiego ustalenia nie prowadzą. Rzecz zasadza się więc na wątpliwości innego rodzaju, a mianowicie na niejednolitym rozumieniu zaproponowanych pojęć: "szczególne osiągnięcia akademickie” oraz "spełnienie ustawowych wymagań". Zespół pierwszy od kandydata wymaga szczególnych osiągnięć naukowych i na takim też poziomie osiągnięć w kształceniu kadry akademickiej (bez ich zdefiniowania). O ile w odniesieniu do drugiego wymagania można a priori przyjąć, że mają one charakter obiektywny, są mierzalne, cechy tej, bez wątpienia, przypisać nie można wymaganiu pierwszemu. Ocena szczególnych osiągnięć naukowych ma w głównej mierze należeć do recenzentów. Sporządzenie recenzji przez uprawnione ustawą osoby i w liczbie przez nią wskazanej jest więc jednym z warunków wypełnienia ustawowego wymagania. Różnice tkwią zatem w treści recenzji i w ich konkluzjach - stanowiskach recenzentów. Jednakże, nawet jeśli odrzuci się tezę postawioną przez zespół drugi o sporządzaniu "grzecznościowych recenzji" ${ }^{40}$ (choć te jako takie nie powinny być tworzone ani dla kogoś, ani przeciwko komuś), rola recenzentów tylko pozornie wzmacnia rozwiązanie tego problemu (abstrahując tu od zagadnienia naruszenia praw autorskich przez kandydata do tytułu). Nie bez uzasadnienia nadal obowiązująca ustawa z 2003 r. wymaga od rady właściwej jednostki organizacyjnej powzięcia, po zapoznaniu się z uchwałą powołanej przez nią komisji zawierającą jej opinię w sprawie nadania lub odmowy nadania tytułu, uchwały popierającej wniosek o nadanie tytułu profesora i przesłania jej CK. Ustawa nie wymaga od rady przekazania CK powziętej przez nią uchwały odmawiającej poparcia wniosku o nadanie tytułu. W tym

\footnotetext{
${ }^{38}$ Projekt pierwszy, s. 100.

${ }^{39}$ Ibidem.

${ }^{40}$ Projekt drugi, s. 161.
} 
zakresie odsyła do odpowiedniego stosowania art. 21 ustawy $^{41}$. Jedynie zatem w przypadku pierwszym CK otrzymuje uchwałę rady i od zajętego przez nią stanowiska oraz stanowiska własnego uzależnia przedstawienie Prezydentowi RP wniosku o nadanie tytułu. CK może podjąć także uchwałę odmowną $w$ tym przedmiocie. Zgodnie z zasadą dwuinstancyjności postępowania administracyjnego zarówno radzie, jak i osobie ubiegającej się o nadanie tytułu profesora służy prawo złożenia wniosku o ponowne rozpatrzenie sprawy. Rozwiązaniom tym przeciwni są autorzy zespołu pierwszego argumentujący swoje stanowisko potrzebą odejścia od traktowania tytułu profesora jako trzeciego, kolejnego i zwykłego etapu awansowego. Z pewnością ich propozycja nie może odnosić się do służącego kandydatowi do tytułu prawa złożenia skargi do sądu administracyjnego.

4. Awans naukowy zwykle prowadzi do awansu zawodowego (wyższego stanowiska). Awans ten $z$ nadaniem tytułu profesora wiążą dwa pierwsze zespoły. Zespół pierwszy za celowe uznaje przyjęcie rozwiązania odpowiadającego tezie, „że najwyższym stanowiskiem naukowo-dydaktycznym jest, na wzór anglosaski, stanowisko «profesor» - jako odpowiednik obecnego stanowiska "profesor zwyczajny»", i rozwiązanie to lansuje "niezależnie od występującego w dniu wszczęcia postępowania lub tylko potencjalnego zatrudnienia na odpowiednich stanowiskach w jednostkach naukowych" ${ }^{\prime 2}$. W konsekwencji dla uzasadnienia odstąpienia od stanowiska profesora nadzwyczajnego proponuje przyjęcie jako najwyższego stanowiska dydaktycznego stanowiska adiunkta-profesora, z wszelkimi uprawnieniami dającymi samodzielność w pracy naukowej i dydaktycznej. Zaproponowane rozwiązanie uzasadnia brakiem celowości powrotu do docentury, jako instytucji międzynarodowo obcej $^{43}$. Za odstąieniem od stanowiska profesora nadzwyczajnego opowiadają się także autorzy zespołu drugiego. W swoich uwagach idą jednak nadal. Zakładają likwidację profesury uczelnianej w ciągu trzech lat od przyjęcia nowej ustawy, tj. od roku akademickiego 2021/2022 ${ }^{44}$. Nadto rekomendują bezwzględny zakaz zatrudnienia (profesorów

${ }^{41} \mathrm{~W}$ przypadku negatywnej opinii komisji oraz podjętej na jej podstawie uchwały rady odmawiającej nadania tytułu jedynie osoba ubiegająca się o nadanie tytułu może wnieść do CK odwołanie (za pośrednictwem rady).

42 Projekt pierwszy, s. 97.

${ }^{43}$ Projekt pierwszy, s. 97-98.

${ }^{44}$ Projekt drugi, s. 40, 158. 
tytularnych) po ukończeniu siedemdziesiątego roku życia „w sektorze publicznym i dawania uprawnień w sektorze niepublicznym", w zamian $\mathrm{za}$ "[w]prowadzenie stanu spoczynku (połączonego z otrzymywaniem $75 \%$ średniej pensji z trzech ostatnich lat pracy zamiast emerytury) dla profesorów tytularnych, którzy przepracowali na pełnym, pierwszym etacie co najmniej 30 lat w państwowych uczelniach lub instytutach PAN i osiągnęli ustawowy wiek emerytalny"45. I choć nie jest to propozycja nowa (środowisko akademickie podnosiło ją już przed znowelizowaniem ustawy o stopniach naukowych i tytułach naukowych $\mathrm{w}$ roku 2011), bez watpienia jest warta poparcia.

Nową formułę awansów naukowych kadry profesorskiej - bez ich powiązania $\mathrm{z}$ nadaniem tytułu profesora i udziału w tym postępowaniu CK jako zbędnej - proponuje natomiast zespół trzeci. Jego założenia sprowadzają się do wyłonienia trzech stanowisk profesora (młodszego, nadzwyczajnego i zwyczajnego), a nadto profesora honorowego ${ }^{46}$. Swoją propozycję opierają na potrzebie odstąpienia od nadawania tytułu profesora oraz od instytucji $\mathrm{CK}^{47}$. Możliwość awansu naukowego i zawodowego nauczycieli akademickich i pracowników naukowych (dla każdego z trzech stanowisk profesora) rezerwuje dla osób ze stopniem naukowym doktora, przy jednoczesnym założeniu pewnej delimitacji między nimi w zakresie wymagań kwalifikacyjnych i warunków zatrudnienia w drodze konkursowej.

Stanowisko młodszego profesora rezerwuje wyłącznie dla osób z innej niż macierzysta uczelni. Walor tego rozwiązania autorzy zespołu trzeciego dostrzegają w dodatkowej sile motywującej do „doskonałości naukowej, w tym do możliwie najwyższej jakości pracy stanowiącej podstawę do nadania stopnia doktora". Zarazem w konsekwencji przyjmuja, że rozwiązanie to służyć będzie także "selektywności w wyłanianiu populacji przyszłych naukowców", jakości nauki i oszczędnego gospodarowania zasobami (poprzez zwiększenie obronionych doktoratów w stosunku do liczby doktorantów). Dla osiągnięcia nakreślonych celów propozycja ta jest mało przekonująca, nawet przy dowiedzionej rozbieżności między liczbą doktorantów a liczbą obronionych prac doktorskich. Po pierwsze dlatego, że nie każda osoba po uzyskaniu stopnia doktora jest zainteresowana zatrudnieniem na uczelni, abstrahując tu także od możliwości w tym zakresie danej jednostki organizacyjnej,

\footnotetext{
${ }^{45}$ Projekt drugi, s. 40.

${ }^{46}$ Projekt trzeci, s. 158-160.

47 Projekt trzeci, s. 117.
} 
po drugie, osoba, która według dotychczasowych przepisów zostaje zatrudniona $\mathrm{w}$ drodze przeprowadzonego konkursu na stanowisko adiunkta, z powodzeniem może wypełniać postulowane przez ten zespół (dla młodszego profesora) funkcje opiekuna studentów studiów pierwszego i drugiego stopnia, może być także promotorem pomocniczym prac doktorskich. Może również korzystać, stosownie do rozwiązań przewidzianych statutem uczelni, z możliwości tworzenia i kierowania wewnętrzną jednostką organizacyjną.

Dyskusyjna jest także propozycja tego zespołu dająca możliwość zatrudnienia na stanowisku profesora nadzwyczajnego. O stanowisko to może ubiegać się doktor posiadający dorobek naukowy, którego aktywność naukowa, w tym w wymiarze międzynarodowym, a także w zakresie współpracy z otoczeniem społeczno-gospodarczym istotnie przewyższa wymagania stawiane młodszemu profesorowi. Wymagania te ma określać uczelnia, z uwzględnieniem jej kategorii naukowej, co dopuszcza możliwe, różne w poszczególnych podmiotach, wymagania $\mathrm{w}$ tym zakresie. Zatrudnienie na stanowisku profesora nadzwyczajnego powinno być limitowane (na czas określony nie krótszy niż sześć lat i nie dłuższy niż osiem lat), z możliwością przedłużenia o kolejne okresy (nie krótsze niż cztery lata i nie dłuższe niż osiem lat). Podobne uwagi zespół trzeci odnosi również do awansu na stopień profesora zwyczajnego, przy czym tutaj podwyższa wymagania w zakresie dorobku naukowego i aktywności naukowej, w tym w wymiarze naukowym, a także współpracy z otoczeniem społeczno-gospodarczym, do istotnie przewyższających wymagania stawiane profesorowi nadzwyczajnemu. Różnica ma się tu sprowadzać do trybu nawiązania stosunku pracy z profesorem zwyczajnym - na podstawie mianowania, na czas nieokreślony, w drodze konkursu lub z "wolnej ręki”. Do rozważenia natomiast autorzy tego zespołu pozostawiają "nadawanie tytularnej profesury jako zwieńczenia kariery osób odchodzących na emeryturę ze stanowiska profesora" 48 .

\footnotetext{
${ }^{48}$ Projekt trzeci, s. 118.
} 